\title{
Marketing Factors That Affecting The Purchase Of Condominium In Bangkok Thailand
}

\author{
Pensri Bangbon ${ }^{1}$, Thanakorn Thanathanchuchot ${ }^{2}$, Yannakorn Toprayoon $^{3}$, PhraSuriya Kongkawai $^{4}$ \\ ${ }^{1}$ Pacific Institute of Management Science \\ ${ }^{2}$ Pathumthani University, \\ ${ }^{3}$ The Association of Researchers of Thailand. \\ ${ }^{4}$ Mahachulalongkornrajavidyalaya University Nakhon Si Thammarat Campus \\ ${ }^{1}$ pensri.2508@gmail.com, ${ }^{2}$ dr.thanakorn@gmail.com, ${ }^{3}$ yannakorn1978@gmail.com, ${ }^{4}$ suriya.Sur@mcu.ac.th
}

\begin{abstract}
The purposes of this research were to study; 1) Purchasing Behavior of Condominium 2) The importance level of factors affecting the purchasing of condominium in Bangkok Thailand.3) The affected purchased level of condominium in Bangkok Thailand. Research and development methodology by quantitative methodology data were collected from used to purchase condominium in Bangkok via accidental sampling of 385 respondents of unknown exactly population. The research instrument were questionnaires. The data were then analyzed by computer software packages, statistic treatments were frequency, percentage, means, standard deviation, and ranking, Pearson Correlation, and Multiple Regression at statistical significance level of .05. The results of the research were as follows: 1) Overall and individual of customers purchased behavior of condominiums were of a high level, raked by mean respectively were: Person influencing Purchasing condominium, Category of condominium by price, and Purpose of purchasing behavior of condominiums.2) Overall and individual of the importance level of the factors affected the purchased condominium in Bangkok were at of a high importance level, raked by mean respectively were : Condominium Location, Promotion, Price of condominium, Brand Equity, Condominium Sales (place), and Condominium room (Product). 3) The marketing factors affected purchased condominium in Bangkok = was 0.898 condominium location, was 0.721 Promotion, was 0.691 Condominium room (Product), was 0.625 Price of condominium, was 0.572 brand equity, was 0.412 condominium sales (place). $(\mathrm{R}$ square $=$ $0.882)$
\end{abstract}

Index Terms

Marketing factors, Purchase condominium

Article Received: 10 August 2020, Revised: 25 October 2020, Accepted: 18 November 2020

\section{Introduction}

Bangkok had 591,138 completed condominium units at the end of 2018. Another 90,000 are now under construction with completion expected in 2019 and subsequent years. Unsold units totaled around 48,000 at the end of May, and the number is likely to increase as more buildings are completed. Overall scores on marketing mix (customer wants and needs, consumer's cost to satisfy, convenienceto buy, and marketing communication)were high on a given rating scale[1]

An oversupply is emerging in the Bangkok condominium market, which has led some developers to pin their hopes on selling more units to foreign buyers, especially Chinese who have become a major market in the last few years. Listed developers are the main drivers of the condominium market, and it is difficult for them to simply stop building. They face pressure to grow every year, in terms of both revenue and profit. While they keep launching new projects that they hope will attract buyers, they are also spending more time trying to offload sold units unlike developers of single detached houses and townhouses, condominium developers can't stop once they start construction. Housing developers, on the other hand, plan their projects in phases and can delay a new phase if market demand is weak. And with Bangkok accounting for about half of all the condos in the country, the glut in the capital is becoming an issue.

But Thai purchasing power has been weak for the last five years or so and has yet to fully recover. Many Thais are still concerned about the political situation and whether the new government can get the economy moving again. Consequently, developers are looking for buyers with high purchasing power in other countries, especially Chinese in Hong Kong and the mainland and other Chinese speakers.

Foreign buyers from Hong Kong and China accounted for $43 \%$ of the 92.16 billion baht transferred from abroad by all foreigners to purchase condominium units in Thailand in 2018 [2], according to the Bank of Thailand. Also Chinese buyers lately have grown more worried about how far their money will go.

The value of the Yuan against the baht has decreased by 10$12 \%$ since the start of 2017. It's not a huge drop compared with what happened to the Russian rouble a decade ago, but it's enough to dent the confidence of some Chinese purchasers. Their concern is that if they buy now and have to take transfer of completed units in one or two years, the Yuan might be even weaker, depending on economic conditions and how the trade war with the United States plays out.

As well, most Chinese buyers in Thailand are looking to buy condominium units in Thailand for investment only, so if the investment return is low, many may not want to transfer their units. In this regard, developers who have been marketing to Chinese buyers need to be truthful about expected returns and must not make any unrealistic promises. But Chinese buyers are still looking to buy condominium units in Thailand, especially Bangkok, as property prices are still lower than in China and can be 
expected to appreciate modestly in the future. As well, they are happy to live, travel and work in Bangkok, given the lower cost of living and greater convenience compared with China.

The most important factor is all Thai developers, due to some are looking to sell their $49 \%$ to Chinese buyers and are not concerned about weak Thai purchasing power. Some have decided to develop new condominium projects because they already have foreign buyers lined up and are confident they can sell their $49 \%$ foreign quota, even if selling the remaining $51 \%$ quota to Thai buyers is far from a certainty these days.

From the problem above that an oversupply is emerging in the Bangkok condominium market, it inspire researcher to study the factors that affect condominium purchasing in Bangkok Thailand. The research finding will be an approach to help condominium developers improve their marketing factors in line with customer requirement.

\section{Research Objectives}

he aims of the research are to investigate

1.Purchasing Behavior of Condominium.

2.The importance level of factors affecting the purchasing of condominium in Bangkok Thailand.

3.The affected purchased level of condominium in Bangkok Thailand.

\section{Scope Of The Research}

Scope of the content: this research are to study; purchasing behavior of condominium, the importance level of factors affecting the purchasing of condominium in Bangkok Thailand. And the affected purchased level of condominium in Bangkok Thailand.

Scope of the population: data will collect from the customers are uses to buy condominium in Bangkok Thailand via accidental sampling of 385 respondents of unknown exactly population.

Location scope: the research area are in Bangkok Thailand.

\section{Hypothesis Of The Research}

Hypothesis: There are relationship between purchasing behavior of condominium and the importance level of factors affecting the purchasing of condominium in Bangkok Thailand.

\section{Research Methods}

This Research and development methodology apply a qualitative approach has investigate 1) Purchased Behavior of Condominium. 2) The importance level of the factors affected the purchased of condominium in Bangkok Thailand. 3) The affected the purchased level of condominium in Bangkok Thailand via quantitative methodology. Data were collected from customer used to purchase condominium in Bangkok Thailand, by accidental sampling of 385 respondents of unknown exactly population. The research instrument were questionnaires. The data were then analyzed by computer software packages, statistic treatments were frequency, percentage, means, standard deviation, and ranking, and Multiple Regression at statistical significance level of .05.

\section{Results}

\section{The results of the research were as follows:}

1) Overall and individual of customers purchased behavior of condominiums were at were of a high level, raked by mean respectively were: Person influencing purchasing condominium, Category of condominium by price, and Purpose of purchasing behavior of condominiums.

2) Overall and individual of the importance level of the factors affected the purchased condominium in Bangkok were at of a high importance level, raked by mean respectively were : Condominium Location, Promotion, Price of condominium, Brand Equity, Condominium Sales (place), and Condominium room (Product)

\section{Factors affected the purchased level of condominium in Bangkok Thailand.}

The analyzed of the Factors affected the purchased level of condominium in Bangkok Thailand by Multi Regression

Table 1 Standard error independent of marketing factors (Durbin-Watson) and relationship between of marketing

\begin{tabular}{|l|l|l|l|l|}
\hline $\begin{array}{l}\text { the factors } \\
\text { affected the } \\
\text { purchased of } \\
\text { condominium } \\
\text { in Bangkok } \\
\text { Thailand }\end{array}$ & SD. & Mean & $\begin{array}{l}\text { Durbin- } \\
\text { Watson }\end{array}$ & VIF \\
\hline $\begin{array}{l}\text { 1.Condominium } \\
\text { room (Product), }\end{array}$ & 0.4024 & 4.11 & 1.8 & 1.797 \\
\hline $\begin{array}{l}\text { 2.Price of } \\
\text { condominium }\end{array}$ & 0.2851 & 4.16 & 2.6 & 1.356. \\
\hline $\begin{array}{l}\text { 3.Condominium } \\
\text { Sales (place), }\end{array}$ & 0.1189 & 4.13 & 4.7 & 2.672 \\
\hline 4.Promotion & 0.2112 & 4.18 & 3.8 & 1.561 \\
\hline $\begin{array}{l}\text { 5.Condominium } \\
\text { Location }\end{array}$ & 0.6123 & 4.19 & 2.4 & 3.589 \\
\hline 6.Brand Equity & 0.3471 & 4.15 & 4.5 & 4.761 \\
\hline
\end{tabular}

From table 1 Standard error independent of marketing factors (Durbin-Watson) and relationship between of marketing factors (VIF) found that

1) Coefficient of Durbin-Watson $=3.14$ between 1.8 4.7 show that there were not relationship between Standard error of marketing factors [3]

2) Coefficient of VIF between $1.356-4.761$ less than 10 show that there were not relationship between of marketing factors [4] 
Table 2 Coefficients the marketing factors affected purchased condominium in Bangkok Thailand by Multiple

\begin{tabular}{|c|c|c|c|c|c|}
\hline \multirow{3}{*}{$\begin{array}{l}\text { The } \\
\text { marketing } \\
\text { factors } \\
\text { affected } \\
\text { purchased } \\
\text { condominium }\end{array}$} & \multicolumn{3}{|c|}{ Regression } & & \\
\hline & \multicolumn{2}{|c|}{$\begin{array}{l}\text { Unstandardiz } \\
\text { ed } \\
\text { Coefficients }\end{array}$} & \multirow{2}{*}{\begin{tabular}{l} 
Standardiz \\
ed \\
Coefficient \\
s \\
\multicolumn{1}{c}{ Beta }
\end{tabular}} & & \\
\hline & B & $\begin{array}{c}\text { Std. } \\
\text { Error }\end{array}$ & & $\mathrm{t}$ & Sig \\
\hline $\begin{array}{l}\text { 1.Condomini } \\
\text { um room } \\
\text { (Product) }\end{array}$ & 0.701 & 0.052 & $0.691 *$ & $\begin{array}{l}1.45 \\
3\end{array}$ & $\begin{array}{l}0.00 \\
2\end{array}$ \\
\hline $\begin{array}{l}\text { 2.Price of } \\
\text { condominium }\end{array}$ & 0.686 & 0.094 & $0.625^{*}$ & $\begin{array}{l}2.65 \\
3\end{array}$ & $\begin{array}{l}0.02 \\
3\end{array}$ \\
\hline $\begin{array}{l}\text { 3. Condomini } \\
\text { um Sales } \\
\text { (place), }\end{array}$ & 0.645 & 0.051 & $0.412^{*}$ & $\begin{array}{l}4.09 \\
8\end{array}$ & $\begin{array}{l}0.02 \\
1\end{array}$ \\
\hline 4.Promotion & 0.782 & 0.133 & $0.721 *$ & $\begin{array}{l}2.14 \\
5\end{array}$ & $\begin{array}{l}0.00 \\
6\end{array}$ \\
\hline $\begin{array}{l}\text { 5.Condomini } \\
\text { um Location }\end{array}$ & 0.912 & 0.211 & $0.898 *$ & $\begin{array}{l}2.98 \\
7\end{array}$ & $\begin{array}{l}0.00 \\
9\end{array}$ \\
\hline $\begin{array}{l}\text { 6.Brand } \\
\text { Equity }\end{array}$ & 0.297 & 0.821 & $0.572 *$ & $\begin{array}{l}2.06 \\
1 \\
\end{array}$ & $\begin{array}{l}0.00 \\
6 \\
\end{array}$ \\
\hline
\end{tabular}

R square adjust $=0.742 \mathrm{R}$ square $=0.758$, Durbin-Watson $=3.134$

Standard error of the estimate $=0.451$

Note *Statistic Level .05

The marketing factors affected purchased condominium in Bangkok $=0.898$ condominium location +0.721 Promotion +0.691 Condominium room (Product) +0.625 . Price of condominium +0.572 brand equity +0.412 condominium sales (place) (At statistical significance level of .05, confidential level 74.2)

\section{Discussions}

According to the results of the research found that The marketing factors affected purchased condominium in Bangkok $=0.898$ Condominium location +0.721 Promotion +0.691 Condominium room (Product) + 0.625.Price of condominium +0.572 brand equity +0.412 condominium sales (place) (At statistical significance level of .05, confidential level 74.2)

The researcher would like to discuss as follow:

1. Condominium location was the first factor that affected purchased condominium in Bangkok of customer (0.898 unit) so the executive of condominium business should to emphasize on selected the location near mass transit (MRT, Shy train), location in prime locations, In the business center, Beside the river, and Good environment respectively it will increase sales volume of condominium and it consistent with the research of Kevin Wongleedee Important marketing decision to purchase condominium: A case study of Bangkok, Thailand. The purpose of this study was to survey important market factors for selling condominium in Bangkok metropolitan. A total of 400 samples were randomly choose from ten different condominium projects in order to gain insight information from their experience of condominium purchasing the research found that the vital marketing factor decision to purchase condominium was location of condominium.[5] 2.Promotion was the second factor that affected purchased condominium in Bangkok of customer (.721 unit) so the executive of condominium business should to improve marketing promotion emphasize on, Get $100 \%$ home loan, No down payment, Fully furnished, Get discount on ownership transfer fee, Twelve months free common area management fee respectively it will increase sales volume of condominium. It consistent with the research of Thaninrath Wonggotwarin 1 and Seongdok Kim . The Products Factors Affecting Purchase Intention: A Case Study of Condominium in Bangkok, Thailand The objective of research is to examine the effect of product's factors which are product quality, service quality, brand image, and product design of condominium toward purchase intention of condominiums in Bangkok. In Thailand, the research found that the products factors purchase condominium was marketing promotion.[6]

3.Condominium room (Product) was the third factor that affected purchased condominium in Bangkok of customer (0.691unit) so the executive of condominium business should to improve marketing promotion emphasize on offer sufficient car park, good building design, multiple-size units, good standard of construction using high quality materials and specifications, and good layout and decoration, it will increase sales volume of condominium and it consistent with the research of J.M. Jayalath. Determinants of Market Value for Condominium Properties: Case Study in Dehiwala, Colombo. to monitor the condominium market, the first issue is to understand what are the determinants of market value for the condominium properties. There are number of factors affecting the market value of condominiums. Based on these factors market value will be changed from one property to another property. Property market buyers and sellers are highly depending on these factors, when buying and selling condominium units. Research found that the Condominium room affected buying condominium.[7]

4. Price of condominium was the fourth factor that affected purchased condominium in Bangkok of customer $(0.625$ unit) so the executive of condominium business should to improve pricing of condominium emphasize on setting,: The price are reasonable of location, Condition of down payment, Terms of payment, Common area maintenance fees (elevators, sprinkler systems, etc.) are reasonable, Value of quality and service it will increase sales volume of condominium and it consistent with the research of Lin. L [8].

The Study of Factors Influencing Chinese Customers' Purchase Decision of Residential Condo in Bangkok The study focuses on factors influencing Chinese customers' purchase decision of residential condo in Bangkok. Research found that price of condominium was very importance factor Correspond to Siripong Nareewong and Nak Guli The most investors placed importance of overall business environment in high level. And, the most investors placed importance[9] and in addition, an interesting point is Mwfeq Haddad, MahfuzJudeh and Shafig Haddad A study of factors influencing consumer buying behavior of condominiums. Case Study in Amman, Jordan The study 
found that gender and age had significant differences in purchasing decisions.[10] However, the marital status and education level were not significantly different in the decision to buy a condominium.

5. Brand equity was the fifth factor that affected purchased condominium in Bangkok of customer ( 0.572 unit) so the executive of condominium business should to improve : Brand Identity (reasonable Price, Privacy, Unique Style), Brand Awareness (condominiums have good reputation and recognition), Brand Personal (condominiums are more luxurious, worth than others), Brand Loyalty (Purchase only although it is expensive ,fabulous developer only ), and Brand Preference (after viewing advertisements, sales staff service), it will increase sales volume of condominium and it consistent with the research of Chuenjit Changchenkit . Influences of Corporate Brand Personality on Buying Decision Process of Residential Condominium in Bangkok to corporate branding can reflect consumers' personality, thus, influencing consumers in buying decision process. The objectives of this research were to study influences of corporate brand personality traits towards consumer decision process of residential condominiums in Thailand. Research found that creating corporate brand personality to self-reflect target consumers' personality was affected purchased condominium.[11]

6. Condominium sales (place) Brand equity was the fifth factor that affected purchased condominium in Bangkok of customer (0.412 unit) so the executive of condominium business should to improve: Condominium had good and secure neighborhoods, Ensuring privacy of residents, Comprehensive range of facilities, Adequate elevators and efficient Machine \& Electricity system, and Easily accessible locations, it will increase sales volume of condominium and it consistent with the research of Chatpramote, A Factor Influencing Customer's Decisions in Buying High-End Condominium in Bangkok among The Address (Sathorn), Keyne (Thonglor) and Noble Refine (Sukumvit). This research aimed to study the marketing mix (7Ps), brand equity and consumer behavior of High-End which significantly influence choice decision in buying High-End condominium in Bangkok, Thailand research found that was selling factor. [12]

\section{Recommendations}

According to the results of research, the researcher would like to suggestion as follow:

1. Condominium location the executive of condominium business should to emphasize on selected the location near mass transit (MRT, Shy train), location in prime locations, location in the business center, beside the river, and good environment respectively.

2.Promotion the executive of condominium business should to improve marketing promotion emphasize on, get $100 \%$ home loan, no down payment, fully furnished, get discount on ownership transfer fee, Twelve months free common area management fee respectively it will increase sales volume of condominium.

3.Condominium room (Product) the executive of condominium business should to improve marketing promotion emphasize on offer sufficient car park, good building design, multiple-size units, good standard of construction using high quality materials and specifications, and good layout and decoration, it will increase sales volume of condominium.

4. Price of condominium the executive of condominium business should to improve pricing of condominium emphasize on setting: The price are reasonable of location, condition of down payment, Terms of payment, common area maintenance fees (elevators, sprinkler systems, etc.) are reasonable, value of quality and service it will increase sales volume of condominium.

5. Brand equity the executive of condominium business should to improve: brand identity (reasonable Price, Privacy, Unique Style), brand awareness (condominiums have good reputation and recognition), brand personal (condominiums are more luxurious, worth than others), brand loyalty (Purchase only although it is expensive, fabulous developer only), and brand preference (after viewing advertisements, sales staff service)

6. Condominium sales (Place) the executive of condominium business should to improve: condominium had good and secure neighborhoods, ensuring privacy of residents, comprehensive range of facilities, adequate elevators and efficient machine \& electricity system, and easily accessible locations, it will increase sales volume of condominium

\section{References}

[1] Wijchulata1 C, and Toprayoon Y.(2017) Marketing Mix of the Chao Phraya Riverside Condominiums, Research and Development JournalSuan Sunandha Rajabhat University 9(1) (January -June) 20,39-49

[2] Bank of Thailand (2019) Retrieved June 20 ,

2019fromhttps://www.bangkokpost.com/b usiness/1701344/chinese-buyers-crucialto-condo-market

[3] Oh, K. (2014),.The Effects of Brand, The international journal of business in society, Vol. 16 Issue March USA.

[4] Ibid

[5] Kevin Wongleedee (2018). Important marketing decision to purchase condominium: A case study of Bangkok, Thailand. Graduate Program Suan Sunandha Rajabhat University, Bangkok, Thailand

[6] Thaninrath Wonggotwarin1 and Seongdok Kim (2017) The Products Factors Affecting Purchase Intention: A Case Study of Condominium in Bangkok, 
Thailand. Graduate School of Business MBA, Assumption University,

[7] J.M. Jayalath (2016), Determinants of Market Value for Condominium Properties: Case Study in Dehiwala, Colombo. University of Sri Jayewardenepura.

[8] Lin. L (2016) the Study of Factors Influencing Chinese Customers' Purchase Decision of Residential Condo in Bangkok. M. B. A., Graduate School, Bangkok University.

[9] Nareewong S. and Guli N.(2017) Faactors Relating to Investors' Investment Decision on Condominiums in Bangkok Metropolis, Phranakhon Rajabhat Research Journal (search Journal 12(1), 152-163.

[10] Mwfeq Haddad, Mahfuz Judeh and Shafig Haddad(2011)."Factors Affecting Buying Behavior of an Apartment an Empirical Investigation in Amman, Jordan”. Research Journal of Applied Sciences, Engineering and Technology, 3(03): 234239

[11] Chuenjit Changchenkit (2016).Influences of Corporate Brand Personality on Buying Decision Process of Residential Condominium inBangkok, Faculty of Business Administration, Marketing Department, Kasesart University, Thailand.

[12] Chatpramote, A (2016).Factor Influencing Customer's Decisions in Buying HighEndCondominium in Bangkok among The Address (Sathorn), Keyne (Thonglor) and Noble Refine (Sukumvit) ,Graduate School, Bangkok University 